\title{
Construction cleared land impact on air quality deterioration: quantification of soil borne dustfall and suspended particulate generation
}

\author{
Arief Sabdo Yuwono ${ }^{1, *}$, Iskandar ${ }^{2}$, Muhammad Fauzan ${ }^{1}$, Elsy Gustika Buana ${ }^{1}$, Agung Abdul Ra'up ${ }^{1}$, and Ety \\ Herwati $^{1}$ \\ ${ }^{1}$ Department of Civil and Environmental Engineering, Bogor Agricultural University (IPB), Indonesia \\ ${ }^{2}$ Department of Soil Science and Land Resources, Bogor Agricultural University (IPB), Indonesia
}

\begin{abstract}
Impact of land clearing during construction that generate dustfall and suspended particulate in ambient air is awfully obvious to observe. According to Indonesian standard as stipulated in Government Regulation (PP) no. 41/1999 pertaining to Air Pollution Control, dustfall and suspended particulate are two important parameters of ambient air quality. However, it remains a problem on how to predict the quantity of dustfall and suspended particulate that is potentially generated during construction land clearing due to lack of prediction method. In this research, a simple way to predict this number has been developed by applying mathematical expressions that are based on a series of laboratory and field experiments covering 15 soil types in Java and Sumatra Islands of Indonesia in 2013-2017. The mathematical formulas can now be implemented directly as a part of an environmental impact assessment, especially in the part of impact prediction of land clearing on air quality change. The formula consists of four parameters, i.e. soil types, local wind velocity, soil moisture content, and percentage of land cover. By inputting these four parameters in the mathematical equation simultaneously, one could directly obtain the quantity of dustfall and suspended particulate generation due to any human activity, such as construction land clearing. The quantity of the generated dustfall is expressed in [ton $/ \mathrm{km}^{2} / \mathrm{month}$ ], whereas the suspended particulate generation is expressed in $\left[\mu \mathrm{g} / \mathrm{Nm}^{3}\right]$ in compliance with the national standard of air quality, i.e. PP No.41/1999. Currently, calculation of the generated dustfall and suspended particulate could be carried out faster and even simpler by using a programmed spreadsheet containing all equations, limitations and terms of conditions that have been compiled during the last five year research campaign.
\end{abstract}

\section{Introduction}

Ambient air quality is an important factor in supporting our life on Earth. The increasing urban development, industry, and urbanization resulted in quality originator of air liquefaction [17]. Based on Indonesian Government Regulation (PP 41/1999) about Air Pollution Control, air pollution is the entry or inclusion of energy, and or other components into the ambient air by human activities, producing a decent aerial, not able to fulfil its functions. Air pollution can be in the form of particles or gases which are released directly or through the reaction of ions, organic or inorganic (secondary process) [6].

Two important parameters of air quality are the dustfall and total suspended particulate (TSP). Dust particles whose size is less than $500 \mu \mathrm{m}$ can be used by dry soil carried by the wind and the flooded volcano eruption [9]. Total suspended particles (TSP) is fine air particles such as dust, vapours, and fumes with a diameter of less than $100 \mu \mathrm{m}$ [15]. The dustfall and the TSP can be issued effectively and efficiently if factors such as wind speed, soil moisture $[7,18]$, and percentage of land cover have been known [23].

Air quality management strategies should consider the relationship of the contribution of various sources of air pollution, sourced from both natural and anthropogenic ones [5]. The management of air quality is carried out to reduce ambient air pollution levels determined by the concentration of dustfall and TSP. Air pollution that takes place for relatively long time will cause respiratory tract diseases. One of the sources of the dustfall and TSP is the sandy soil [8].

Meteorological conditions, the surface of the ground, and the stability of the atmosphere are some of the factors

\footnotetext{
* Corresponding author: arief.sabdo.yuwono66@gmail.com
} 
that affect the generation of dustfall $[1,11]$. According to Laurent et al. [13], generation of dust is influenced by local wind speed that is a function of surface roughness, soil texture, and soil moisture content. Factors affecting soil erosion are: energy (erosivity), the sensitivity of soils (erodibility), and protection of soil [12, 16, 19, 20]. Dustfall emission factors and TSP of different types of soil affect ambient air quality [10].

Availability of spreadsheet that can be applied to calculate automatically the magnitude of the generation of dustfall and TSP from ground surface that is affected by the environmental conditions and the local climate condition is one of the important contributions for stakeholders in Indonesia. The research was conducted to build Microsoft Excel-based software that can be easily accessed by all people to calculate the magnitude of the generation of dustfall and TSP from different types of soil originated from Java and Sumatra islands.

The first objective of the research was to develop a Microsoft Excel-based spreadsheet that enables an automatic calculation of dustfall and Total Suspended Particulate (TSP) generation. The second objective was to perform a direct measurement of dustfall and TSP generation in the field to validate the mathematical models used in the spreadsheet.

\section{Material and Method}

Research was carried out in a laboratory scale tunnel in Department of Civil and Environmental Engineering, Bogor Agricultural University (IPB) to develop the mathematical models as well as directly in an open area in Bandar Lampung Municipality of Sumatra Island during February-May 2018. Soil samples were collected from the field and then observed in the laboratory tunnel. Instruments used in the research included high volumetric air sampler (HVAS), digital anemometer, soil moisture meters, analytical balance, petri dish, paper filter $10 \mu$, universal oven, stopwatch (time reporter), and computers. The materials used were distilled water and the soil samples.

Data were collected from several types of soil found in Java and Sumatra Islands, based on the research conducted in 2014-2016. The data collected covered the mathematical equations to calculate the generation of dustfall and TSP from the soil i.e., emission factors of dustfall and TSP that were classified according to the soil types. The next steps were compilation of data, spreadsheet testing, and field test of the equation.

Field test was carried out by direct measurement on the generated dustfall and TSP on the land where samples were taken from Bandar Lampung Municipality. The soil type found in the Neighbourhood of the sampling point was Latosol. Primary data collected from field include local wind speed, soil moisture content, and percentage of land cover. The additional data that were air pressure and temperature at the measurement time.

The samples collected from the field were then analysed in the laboratory to find the quantity of the generated dustfall and TSP. The quantity of the dustfall and TSP which has been obtained were then put into the equation list. The field test results from the field were used to find the difference between TSP and dustfall generation of laboratory and field equations.

The spreadsheet was developed by using the Microsoft Excel software combined with Visual Basic for Application (VBA). The spreadsheet is based on the input of soil type, soil moisture, wind speed, and percentage of land cover, resulting in the amount of dustfall and TSP generation automatically. The equation of every type of soil was put into VBA so that it simplifies the calculation process. Steps of the research were described in the form of flowchart as presented in Figure 1.

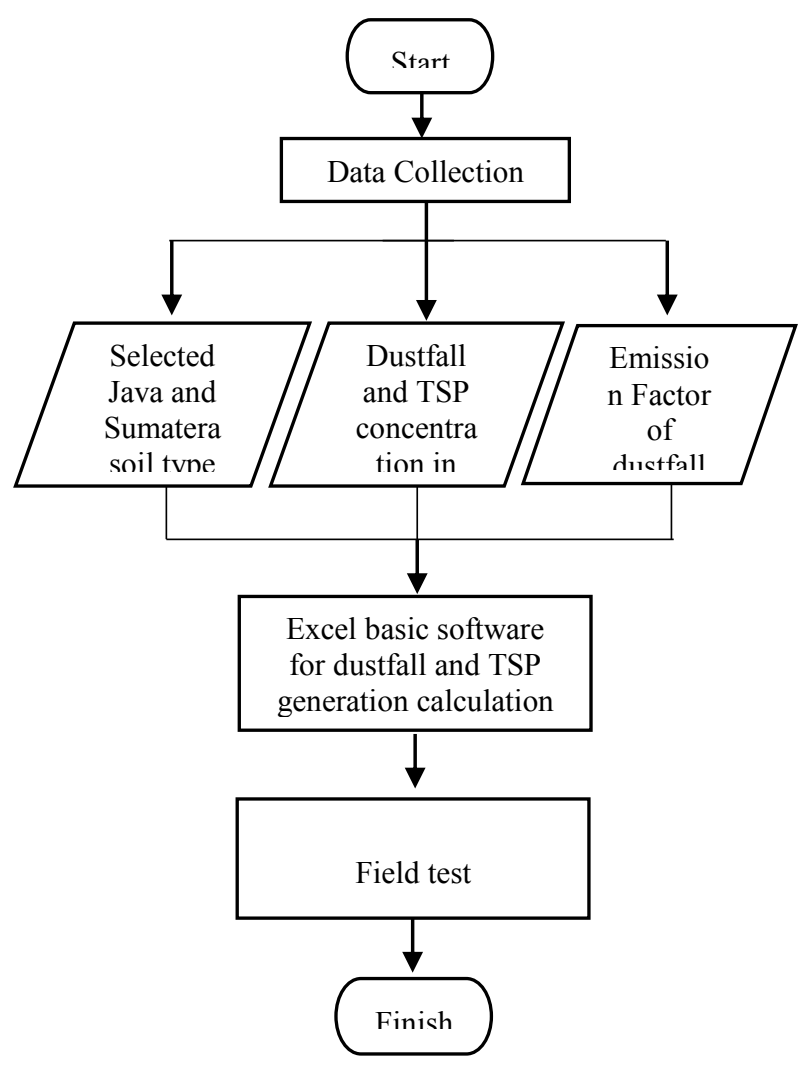

Fig. 1 The steps of research

\section{Results and Discussions}

\subsection{Forms of Equation Based on Conventional Analysis}

Conventional analysis that was used here is in accordance with the research conducted by Yuwono et al. [22]. Emission factor equations were compiled based on the value of the best of coefficient of determination $\left(\mathrm{R}^{2}\right)$. The equations obtained from conventional analysis in determining the emission factors for dustfall and TSP are presented in Table 1. 
Table 1. Emission Factor Equations of Dustfall and TSP with Conventional Analysis

\begin{tabular}{|c|c|}
\hline Soil type & Formula \\
\hline \multirow{2}{*}{ Alluvial } & $E_{D F}=\left(146.9 U^{2}-258.5 \mathrm{U}+120.5\right) \times 0.4+(-2.6 \mathrm{M}+81.2) \times 0.2+\left(0.002 \mathrm{~L}^{2}+0.1 \mathrm{~L}+5.7\right) \times 0.4$ \\
\hline & $\mathrm{E}_{\mathrm{TSP}}=(103.8 \mathrm{U}+75.6) \times 0.3+(-18.7 \mathrm{M}+765.4) \times 0.3+(-1.1 \mathrm{~L}+152.2) \times 0.4$ \\
\hline \multirow{2}{*}{ Andosol } & $E_{D F}=\left(3.8 \mathrm{e}^{0.07 U}\right) \times 0.3+\left(8.2 \mathrm{e}^{-0.02 \mathrm{M}}\right) \times 0.3+\left(6.3 \mathrm{e}^{-0.01 \mathrm{~L}}\right) \times 0.4$ \\
\hline & $\mathrm{E}_{\mathrm{TSP}}=(28.6 \ln (\mathrm{U})+76.3) \times 0.1+(-56.4 \ln (\mathrm{M})+311.8) \times 0.4+(-6.8 \ln (\mathrm{L})+107.3) \times 0.5$ \\
\hline \multirow{2}{*}{ Grumusol } & $E_{D F}=\left(11.0 U^{2}-15.5 \mathrm{U}+13.8\right) \times 0.3+\left(0.1 \mathrm{M}^{2}-8.1 \mathrm{M}+158.0\right) \times 0.3+(-0.1 \mathrm{~L}+5.3) \times 0.4$ \\
\hline & $\mathrm{E}_{\mathrm{TSP}}=(128.2 \mathrm{U}-61.0) \times 0.3+(-16.6 \mathrm{M}+667.4) \times 0.3+(-1.5 \mathrm{~L}+171.9) \times 0.4$ \\
\hline \multirow{2}{*}{ Latosol } & $E_{D F}=\left(30.7 U^{2}-47.6 U+23.7\right) \times 0.3+(-1.1 \mathrm{M}+34.9) \times 0.3+\left(0.0005 \mathrm{~L}^{2}-0.2 \mathrm{~L}+9.1\right) \times 0.4$ \\
\hline & $\mathrm{E}_{\mathrm{TSP}}=(90.4 \mathrm{U}+30.9) \times 0.3+(-19.8 \mathrm{M}+732.0) \times 0.3+(-1.6 \mathrm{~L}+114.3) \times 0.4$ \\
\hline \multirow{2}{*}{ Mediterranean } & $E_{D F}=\left(0.5 \mathrm{e}^{4.16 \mathrm{U}}\right) \times 0.3+\left(210.7 \mathrm{e}^{-0.18 \mathrm{M}}\right) \times 0.3+\left(1.8 \mathrm{e}^{-0.02 \mathrm{~L}}\right) \times 0.4$ \\
\hline & $\mathrm{E}_{\mathrm{TSP}}=\left(32.0 \mathrm{e}^{1.37 \mathrm{U}}\right) \times 0.3+\left(178.1 \mathrm{e}^{-0.04 \mathrm{M}}\right) \times 0.3+\left(123.8 \mathrm{e}^{-0.02 \mathrm{~L}}\right) \times 0.4$ \\
\hline \multirow{2}{*}{ Regosol } & $E_{D F}=\left(4.1 \mathrm{e}^{1.58 \mathrm{U}}\right) \times 0.3+\left(24.0 \mathrm{e}^{-0.04 \mathrm{M}}\right) \times 0.3+\left(99.0 \mathrm{e}^{-0.14 \mathrm{~L}}\right) \times 0.4$ \\
\hline & $\mathrm{E}_{\mathrm{TSP}}=\left(39.6 \mathrm{e}^{-1.09 \mathrm{M}}\right) \times 0.3+\left(157.1 \mathrm{e}^{0.03 \mathrm{U}}\right) \times 0.3+\left(110.4 \mathrm{e}^{-0.02 \mathrm{~L}}\right) \times 0.4$ \\
\hline \multirow{2}{*}{ Red Yellow Podsolik } & $E_{D F}=(16.0 U-1.6) \times 0.3+(-2.3 \mathrm{M}+102.0) \times 0.3+(-0.1 \mathrm{~L}+7.3) \times 0.4$ \\
\hline & $\mathrm{E}_{\mathrm{TSP}}=(6.8 \mathrm{U}+14.4) \times 0.1+(-5.7 \mathrm{M}+240.9) \times 0.4+(-0.2 \mathrm{~L}+10.7) \times 0.5$ \\
\hline \multirow{2}{*}{$\begin{array}{l}\text { Complex Red Yellow } \\
\text { Mediterranean and } \\
\text { Grumusol } \\
\end{array}$} & $E_{D F}=\left(4.4 \mathrm{e}^{1.19 \mathrm{U}}\right) \times 0.4+\left(645.6 \mathrm{e}^{-0.10 \mathrm{M}}\right) \times 0.2+\left(15.7 \mathrm{e}^{-0.02 \mathrm{~L}}\right) \times 0.4$ \\
\hline & $\mathrm{E}_{\mathrm{TSP}}=\left(27.0 \mathrm{e}^{1.22 \mathrm{U}}\right) \times 0.4+\left(72.5 \mathrm{e}^{0.003 \mathrm{M}}\right) \times 0.2+\left(66.0 \mathrm{e}^{-0.01 \mathrm{~L}}\right) \times 0.4$ \\
\hline \multirow{2}{*}{$\begin{array}{l}\text { Complex Red Yellow } \\
\text { Podsolik Latosol } \\
\text { Litosol }\end{array}$} & $E_{D F}=(4.6 U+2.9) \times 0.1+(-1.7 \mathrm{M}+72.1) \times 0.4+(-0.04 \mathrm{~L}+4.3) \times 0.5$ \\
\hline & $\mathrm{E}_{\mathrm{TSP}}=(22.5 \mathrm{U}+43.0) \times 0.2+(-5.4 \mathrm{M}+274.4) \times 0.4+(-0.4 \mathrm{~L}+57.1) \times 0.5$ \\
\hline
\end{tabular}

Emission factor equations presented in Table 1 are the form of simplification to facilitate estimation of TSP and dustfall generations in the field. These equations were obtained from a series of experiments conducted in a laboratory scale tunnel. Each soil type had varying emission factor equations which can be linear, exponential, or logarithmic shape in accordance with the highest value of $\mathrm{R}^{2}$. The equations were developed based on the field data. Hence, the amount of the generated dustfall and TSP measurement results in the field could be different from the estimated results by using this equation.

\subsection{Dustfall and TSP Generation Calculation Spreadsheet}

Estimation of dustfall and TSP generation in an area needs to be conducted to determine the status of air quality of the area. The estimation can be done automatically using programmed spreadsheet based on the soil type, wind speed, soil moisture content, and percentage of land cover.

Dustfall and TSP generation equations were obtained from a series of researches that has been conducted by Yuwono et al. [22], Amaliah et al. [2], Rochimawati et al. [15], Yuwono et al. [23], Azmi et al. [4], Hamiresa et al. [10], and Yuwono et al. [21]. The equation used in the reference to the equation results in a conventional analysis has been developed by Yuwono et al. (2014). This is because the equation shows better results than the ones obtained by multivariate analysis, as has been demonstrated through the research of Suri (2017).

TSP and dustfall generation calculation spreadsheet was created by using Microsoft Excel software with Visual Basic for Application (VBA). The spreadsheet is based on the input of soil type, soil moisture, wind speed, and land cover, resulting in a dustfall and TSP generation automatically. There are nine (9) soil types entered into the VBA, i.e. Alluvial, Andosol, Grumusol, Regosol, Latosol, Mediterranean, Red Yellow Podsolik, Complex Red Yellow Mediterranean and Grumusol, and Complex Red Yellow Podsolik Latosol Litosol. The TSP and dustfall generation spreadsheet display is automatically using Microsoft Excel applications as presented in Figure 2 .

TSP and dustfall generation program calculation is based on the input soil type, wind speed, soil moisture content, and the percentage of land cover. Based on the research that has been carried out by Armando [3], dustfall generation of Regosol soil from Bandar Lampung was influenced by wind speed amounted to $99.09 \%$, soil moisture content $99.45 \%$ and percentage of land cover $86.74 \%$. Meanwhile, the TSP generation of Regosol soil were influenced by wind speed amounted to $99.94 \%$, soil moisture content $99.09 \%$ and percentage of land cover $94.15 \%$.

The calculation spreadsheet is now to help the stakeholders to predict the TSP and dustfall generation in a region. Spreadsheet usage procedure is presented in Figure 3. 


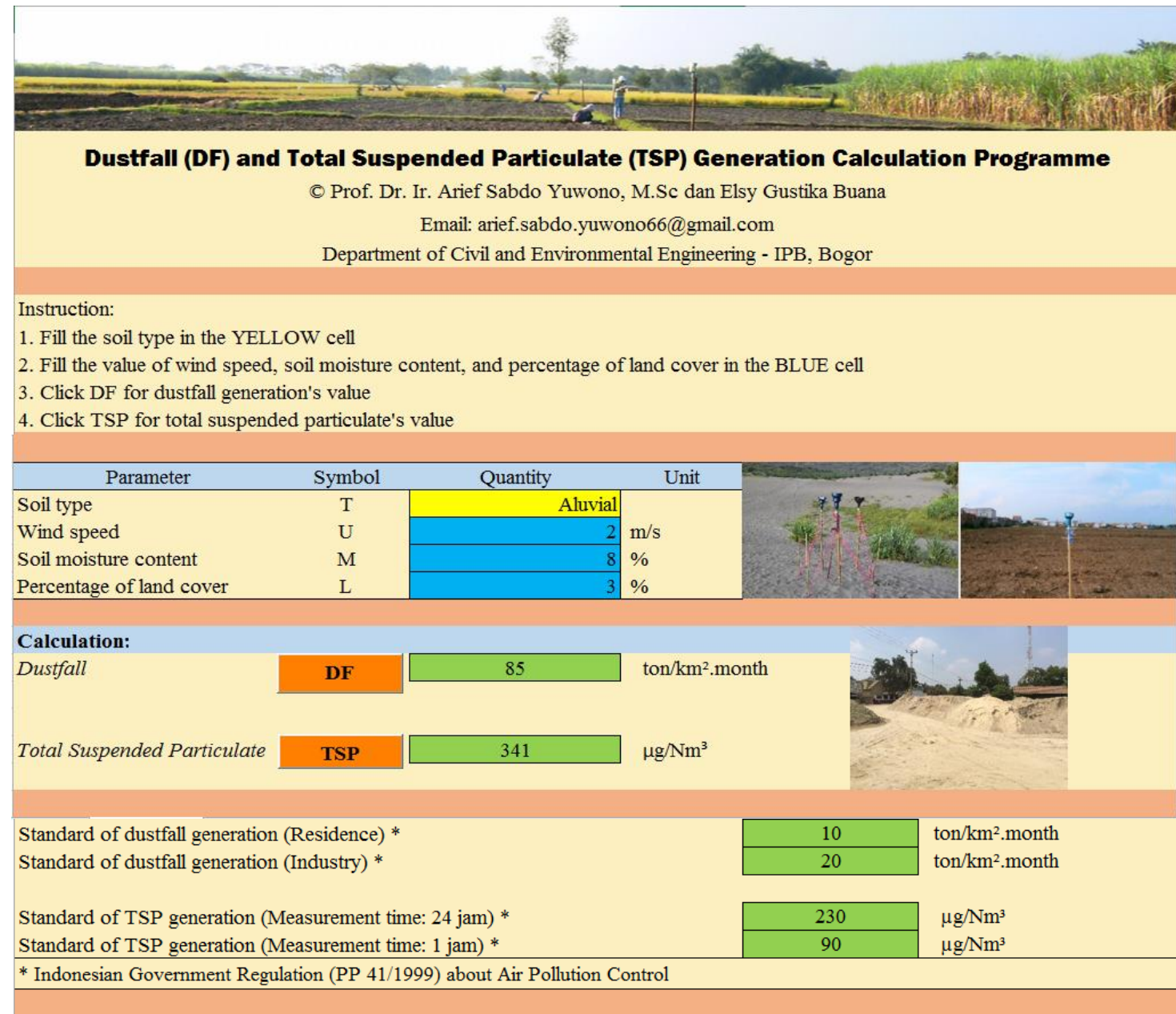

Fig. 2 Spreadsheet display with example of calculation

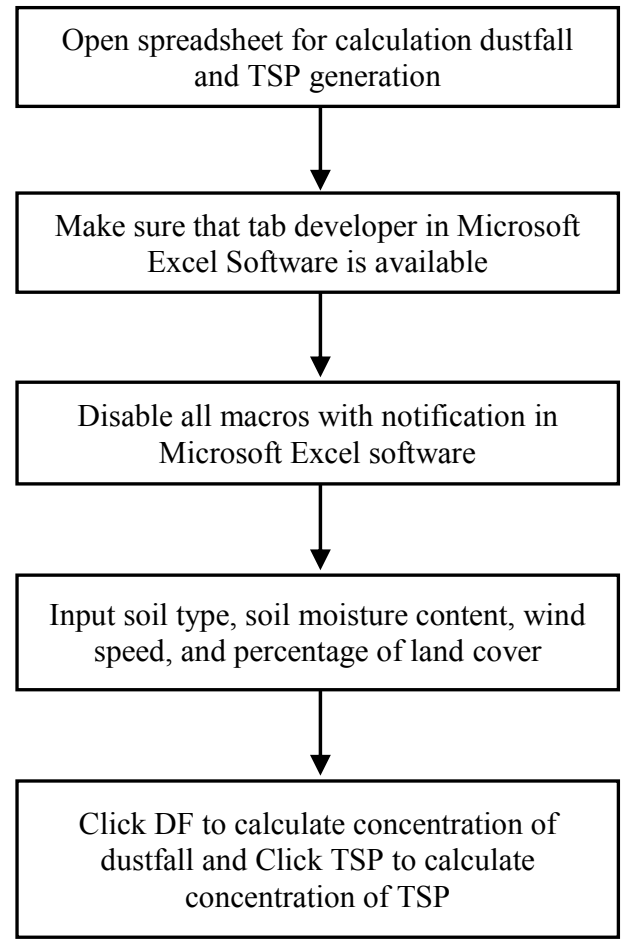

Fig. 3 The steps of software usage 


\subsection{Calculation Examples of Dustfall and TSP Generation}

Examples of dustfall and TSP generation calculation are presented in the following. The soil type of Red-Yellow Podsolik was taken from the Sub district Jasinga, Bogor district with the following data:
- Wind speed

- Soil moisture content $: 1.7 \mathrm{~m} / \mathrm{s}$

- Percentage of land cover

$: 7.5 \%$

$: 2.3 \%$

The calculation result obtained through the calculation program is presented in Figure 4.

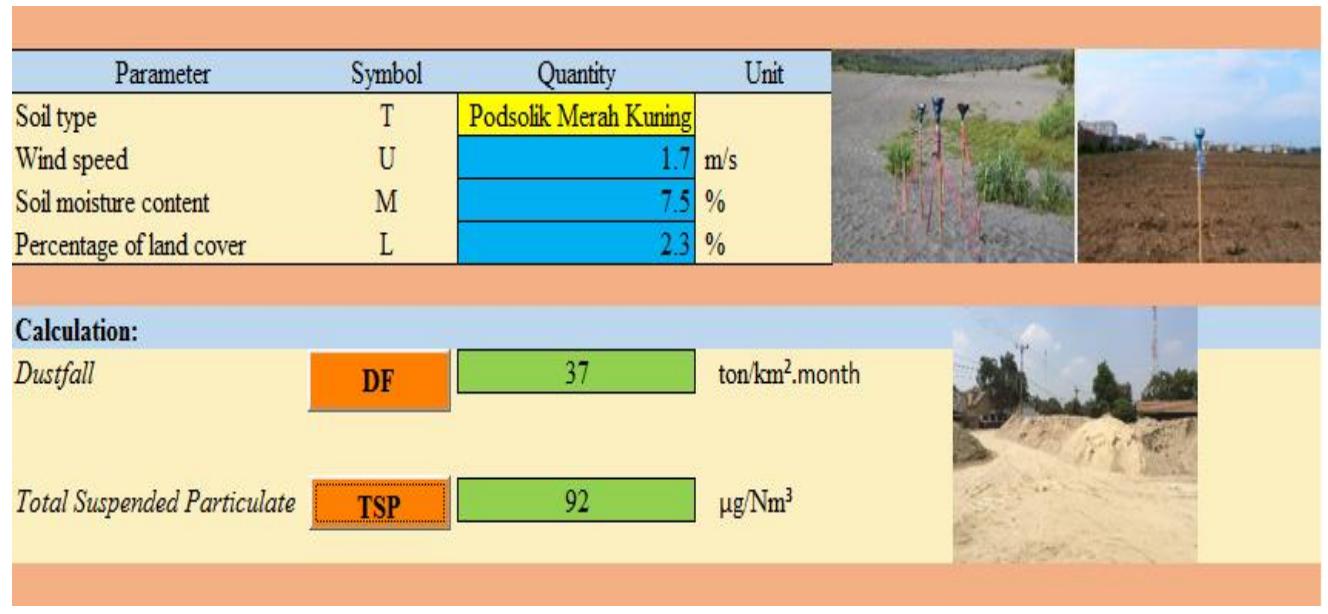

Fig. 4 The calculation result of dustfall and TSP generation

The concentration of dustfall and TSP generation correlated positively with wind speed. The higher the wind speed, the greater dustfall and TSP generation. Meanwhile, dustfall and TSP generation correlated negatively with soil moisture content and percentage of land cover. Thus, the higher the moisture content of soil and land cover, the lower the dustfall and TSP generation.

Different soil type with the same data of wind speed $(\mathrm{U})$, soil moisture content $(\mathrm{M})$, and percentage of land cover (L) will produce different dustfall and TSP generation. It is caused by the higher coefficient of determination $\left(\mathrm{R}^{2}\right)$ and the regression equation in every soil type is different.

The concentration of TSP and dustfall generation obtained from automatic calculation results can be directly compared to the standard as prescribed in the Indonesian Government Regulation (PP 41/1999) about Air Pollution Control. The amount of the dustfall and TSP generation standard are also presented in the program's calculation, so that the user can easily notice the standard. Hence, decision-making or policy taking will also become faster.

\subsection{The Concentration of Dustfall and TSP Generation Based on Field Test}

Data from the field test was performed within two-day campaign in Bandar Lampung Municipality of Lampung Province, Indonesia. The types of soil found at that location is Latosol. Data complication in the field was conducted based on the measurement result of wind speed and soil moisture content measured directly in the field.
Measurements of TSP were performed for 1 hour using HVAS, whereas, the measurement of dustfall was made over 29 hours using dustfall canister. The measurement of wind speed and soil moisture content was performed every 20 minutes for at least 1 hour. Each measurement was replicated four times. Results of dustfall and TSP in the field are presented in Table 2.

Table 2. Results of field test

\begin{tabular}{|c|c|c|c|}
\hline \multirow{3}{*}{ Soil type } & $\begin{array}{c}\text { In the field } \\
\text { (a) }\end{array}$ & $\begin{array}{c}\text { Automatic } \\
\text { calculation } \\
\text { Programme } \\
\text { (b) }\end{array}$ & $\begin{array}{c}\text { Difference* } \\
\text { (c) }\end{array}$ \\
\hline \multirow{3}{*}{ Latosol } & \multicolumn{3}{|c|}{ Dustfall Generation (ton $/ \mathrm{km}^{2}$. month) } \\
\cline { 2 - 4 } & 6.3 & 13.2 & 6.9 \\
\cline { 2 - 4 } & \multicolumn{3}{|c|}{ TSP Generation $\left(\mu \mathrm{g} / \mathrm{m}^{3}\right)$} \\
\cline { 2 - 4 } & 33.2 & 193.3 & 160.1 \\
\hline $\mathrm{c}=|\mathrm{b}-\mathrm{a}|$
\end{tabular}

The direct measurement result in the field indicates that there is a difference between dustfall and TSP generation in the field and the results of calculations using the program calculations. The difference could be caused by several factors, such as wind speed and soil moisture content which are unstable in the field, the land cover percentage in the field, human activity in the local environment, and the topography of the region. 
The amount of the difference between the calculation of dustfall and TSP generation in the field and computation by using the automated calculation spreadsheet was also influenced by the length of measurement time. The longer time measurements of TSP and dustfall generation, the smaller the amount obtained. Moreover, the difficulty to predict meteorological conditions in the area could also affect the differences greatly.

\section{Conclusions}

The conclusions that can be drawn from the study are as follows:

a. Dustfall and TSP calculation spreadsheet was developed based on Microsoft Excel software and Visual Basic for Application (VBA). The spreadsheet is based on inputs including soil type, wind speed, soil moisture content, and percentage of land cover to calculate dustfall and TSP generation.

b. Dustfall and TSP generation in the field and results of calculations using the calculation spreadsheet was different. It could be caused by wind speed and soil moisture content which is unstable in the field, the type of land cover in the field, human activity in the local environment, and the topography of the region.

Authors wish to thank all research assistants and technicians during field experiments as well as laboratory analysts for their helpful services. The research was conducted with financial support from The Ministry of Research, Technology and Higher Education, Republic of Indonesia, under BOPTN research grant scheme coordinated by Research Institute and Community Service (LPPM), Bogor Agricultural University (IPB).

\section{References}

1. E.K. Akpinar, S. Akpinar, H.F. Oztop, JUEE 3, 1 (2009)

2. L. Amaliah, A.S. Yuwono, B. Mulyanto, SJET 2, 3B (2014)

3. Y. Armando. 2016. Dustfall and Total Suspended Particulate of Land Regosol at Various Wind Speed, Soil Moisture Content, and Land Cover. [Undergraduate Thesis]. Bogor (ID): Bogor Agricultural University.

4. A. Azmi, A.S. Yuwono, Erizal, A. Kurniawan, B. Mulyanto, ARPN JEAS 10, 18 (2015)

5. A.O.M. Carvalho, M.D.C. Freitas, J. Environ. Sci. 4, 184-191 (2011)

6. J.D. Duh, V. Shandas, H. Chang, L.A. George, Sci. Total Environ. 400, 238-256 (2008)

7. F. Fecan, B. Marticorena, G. Bergametti, Ann. Geophysicae 17, 149-157 (1999)

8. J.L. Feng, L.P. Zhu, J.T. Ju, L.P. Zhou, X.L. Zhen, W. Zhan, S.P. Gao, Geochem. J. 42, 221-236 (2008)

9. C. Hai, C. Yuan, G. Liu, X. Li, F. Zhang, X. Zhang, Water, Air, Soil Pollut. 190, 27-34 (2007)
10. G. Hamiresa, A.S. Yuwono, S. Anwar, ARPN JEAS 11, 21 (2016)

11. J. Kang, S. Yoon, Y. Shao, S. Kim, J. Gheophys. Res. 116, D9 (2011)

12. I. Koren, Y.J. Kaufman, Geophys. Res. Lett. 31, 6 (2004)

13. B. Laurent, B. Marticorena, G. Bergametti, F. Mei, Glob. Planet. Change 52, 121-141 (2006)

14. [PRI] Pemerintah Republik Indonesia. 1999. Peraturan Pemerintah Republik Indonesia Nomor 41 tahun 1999 tentang Pengendalian Pencemaran Udara. Kementerian Lingkungan Hidup. Jakarta. (1999) [in Indonesian]

15. N.R. Rochimawati, A.S. Yuwono, S.K. Saptomo, ARPN J. Sci. Tech. 4, 6 (2014)

16. Z. Shang, L. Cheng, Q. Yu, L. He, Z. Lu, OJAP 1, 67-73 (2012)

17. WI. Suri. 2017. Multivariate and Conventional Analysis to Determine the Emission Factors of Dustfall and TSO in Ambient Air. [Undergraduate Thesis]. Bogor (ID): Bogor Agricultural University.

18. X. Wang, J.C. Chowa, S.D. Kohla, L.N.R. Yatavelli, K.E. Percy, A.H. Legge, J.G. Watson, AeolianResearch 18, 11 (2015)

19. R. Washington, M.C. Todd, N.J. Middleton, A.S. Goudie, Ann. Assoc. Am. Geogr. 93, 2 (2003)

20. M. Yoshioka, N.M. Mahowald, J.L. Dufresne, C. Luo, J. Geophys. Res. 110, D18 (2005)

21. A.S. Yuwono, M. Khoirunnisa, M. Fauzan, Iskandar, R.A. Regia, IJAES 12, 11 (2017)

22. A.S. Yuwono, A. Lia, N.R. Rochimawati, A. Kurniawan, M. Budi, ARPN JEAS 9, 9 (2014)

23. A.S. Yuwono, F. Mulyani, C.R. Munthe, A. Kurniawan, B. Mulyanto, IJAES 10, 20 (2015)

24. A.S. Yuwono, B. Mulyanto, M. Fauzan, C.R. Munthe, IJAES 11, 4 (2016). 